\title{
Elevation and vegetation influences on soil properties in Chilean Nothofagus forests
}

\author{
Influencia de la elevación y la vegetación sobre las propiedades del suelo de los bosques \\ chilenos de Nothofagus
}

\author{
KELLY L.M. DECKER ${ }^{1,2} \&$ R.E.J. BOERNER \\ Department of Evolution, Ecology, and Organismal Biology, Ohio State University, Columbus, Ohio 43210 USA; \\ e-mail: kdecker@mail.arc.nasa.gov \\ ${ }^{1}$ (author for correspondence) \\ ${ }^{2}$ Current Address: Ecosystem Science and Technology Branch, NASA-Ames Research Center, Mail Stop 242-4, \\ Moffett Field, California 94035, USA
}

\begin{abstract}
We measured net nitrogen mineralization, net nitrification, proportional nitrification, and total inorganic nitrogen, available phosphorus, and soil organic carbon in five Andean forested stands in an attempt to resolve the relative influence of elevation and forest canopy composition on soil organic matter and nutrient dynamics in this ecosystem type. Our five forested study sites were within a contiguous Nothofagus forest that ranged from 1,280 to $1,700 \mathrm{~m}$ elevation in the central Chilean Andes. The five sites consisted of three single species stands, one each of the low elevation deciduous $N$. obliqua, the evergreen $N$. dombeyi, or the high elevation deciduous $N$. pumilio, as well as two mixed evergreen-deciduous stands. There was no statistically significant relationship of nitrogen mineralization or phosphorus with elevation. In contrast, there were statistically significant, though weak, negative relationships between elevation and net nitrification, proportional nitrification, soil $\mathrm{pH}$ and organic carbon. In general, soils from the $N$. obliqua stand had higher levels/rates of nitrification, soil organic carbon content, soil $\mathrm{pH}$, and plant available phosphorus than soils form the other single species stands. In contrast, the $N$. dombeyi and $N$. pumilio stands had lower rates of nitrification and soil $\mathrm{pH}$ than did the $N$. obliqua stand. The evergreen-deciduous mixed stands tended to be intermediate in soil properties. These results demonstrate that vegetation, particularly the balance of evergreen and deciduous species, exerts stronger control over soil chemical and biochemical properties than the climate variations induced by $350 \mathrm{~m}$ in elevation, even where the evergreen and deciduous species are closely-related angiosperms.
\end{abstract}

Key words: Chilean Andes, leaf lifespan, nitrogen mineralization, nitrification, Nothofagus, soil carbon.

\section{RESUMEN}

Medimos la mineralización neta de nitrógeno, la nitrificación, el total de nitrógeno disponible, el fósforo disponible y el carbono orgánico del suelo en cinco rodales forestales andinos con el propósito de separar la influencia relativa de la elevación y la composición del dosel del bosque sobre la materia orgánica del suelo y la dinámica de los nutrientes en este tipo de ecosistema. Nuestros cinco sitios se encuentran dentro de un bosque continuo de Nothofagus en los Andes chilenos, a altitudes entre 1.280 y $1.700 \mathrm{~m}$. De los cinco rodales, tres fueron monoespecíficos, dominados por $N$. obliqua (especie decidua de las tierras bajas), N. dombeyi (siempreverde) y N. pumilio (especie decidua de las tierras altas). Los otros dos rodales fueron de composición mixta. No encontramos relación significativa entre la elevación y la mineralización de nitrógeno o de fósforo. Por otra parte, se dieron relaciones negativas entre la elevación y la nitrificación, el pH del suelo y el carbono orgánico. En general, los suelos bajo $N$. obliqua presentaron tasas mayores de nitrificación, mayor contenido de carbono orgánico, $\mathrm{pH}$ del suelo más alto y más fósforo disponible que los suelos bajo los otros rodales monoespecíficos. Los suelos de rodales mixtos mostraron propiedades intermedias. Estos resultados muestran que la vegetación, en particular el balance de especies deciduas y siempreverdes, ejerce un control más fuerte sobre las propiedades químicas y bioquímicas del suelo que las variaciones climáticas producidas por la diferencia de $350 \mathrm{~m}$ de elevación, aun cuando estas especies deciduas y siempreverdes son angiospermas estrechamente emparentadas.

Palabras clave: Andes chilenos, longevidad de las hojas, mineralización de nitrógeno, nitrificación, Nothofagus, carbono del suelo. 


\section{INTRODUCTION}

Upon approaching tree line along latitudinal or elevational gradients in the northern hemisphere, there is a marked shift in woody plant composition from deciduous to evergreen species. This shift in leaf life span has long been attributed to long term selection for nutrient conservation and carbon acquisition in marginal habitats, such as those near tree line. This view has been confirmed by a variety of studies, most of which compare ecophysiological traits of evergreen conifers to deciduous angiosperms (Chabot \& Hicks 1982, Boettcher \& Kalisz 1990).

In contrast to the prevailing pattern in the northern hemisphere, the elevational distribution of species of Nothofagus (southern beech) in the Andes of central Chile does not shift uniformly from deciduous to evergreen with increasing elevation (Donoso 1974). Although deciduous species of Nothofagus do dominate the lower foothills and are replaced by evergreen species at mid elevations, it is the deciduous species $N$. pumilio or $N$. antarctica that predominantly dominate near tree line. The combination of this unexpected pattern of species distribution with elevation (from a northern hemisphere perspective), and the close evolutionary relationship of the sympatric Nothofagus species of this region presents an ideal opportunity to test hypotheses concerning how differences in leaf lifespan relate to soil properties, without the confounding problem of comparing evergreen gymnosperms to deciduous angiosperms.

Release of $\mathrm{N}$ through the decomposition of leaf litter is sensitive both to microclimate and to the nutritional quality of the decomposing material (Meentemeyer 1978). As a direct consequence of changes in microclimate, the rate of decomposition decreases with increasing elevation (Shanks \& Olsen 1961). In addition, the shift from deciduous (angiosperm) litter with relatively low lignin content and $\mathrm{C}: \mathrm{N}$ ratio to evergreen (gymnosperm) litter with high lignin content and $\mathrm{C}: \mathrm{N}$ ratio reduces decomposition (Meentemeyer 1978), especially in cases where evergreens replace deciduous species at high elevations. Finally, the long term effect of deposition and decomposition of deciduous versus evergreen litters may further affect both the chemical and biological characteristics of the soils under those trees in such a manner as to produce an environment under evergreens that is less conducive to decay and nutrient mineralization than that under deciduous species (Alway et al. 1933).
Thus a shift in species from deciduous to evergreen vegetative cover may amplify the effect of increasing elevation by further reducing the rate at which organic matter is broken down.

The Chilean Nothofagus system is an ideal one in which to attempt to separate the relative effects of elevation and the consequences of leaf longevity on soil characteristics and processes because evergreen and deciduous Nothofagus species occur in both pure and mixed stands along an elevation gradient. Our overarching objective was to compare the relative influences of elevation and vegetation type (i.e., evergreen versus deciduous) on soil $\mathrm{N}$ ( $\mathrm{N}$ mineralization and nitrification), $\mathrm{P}, \mathrm{pH}$ (as an integrating measure of base cation availability), and soil organic $\mathrm{C}$ in this system. In addition, as there is little deposition of anthropogenically-produced $\mathrm{N}$ from the atmosphere in most of Chile, these forests also present an opportunity to quantify rates of $\mathrm{N}$ mineralization and nitrification in temperate broad-leaved forests not under such stress. Specifically, we sought to test the hypothesis that soil conditions caused by (1) high elevation, and (2) the presence of evergreen hardwoods will be characterized by greater amounts of organically-bound $\mathrm{C}$, lower $\mathrm{pH}$, and lower amounts of available $\mathrm{N}$ and $\mathrm{P}$ when compared with soil conditions at lower elevations and/or in deciduous hardwood stands.

\section{MATERIAL AND METHODS}

\section{Study sites}

The area in which our specific study sites occur is a pure Nothofagus forest in the Chilean Andes east of the village of Las Trancas $\left(71^{\circ}\right.$ $\left.25^{\prime} \mathrm{W}, 36^{\circ} 55^{\prime} \mathrm{S}\right)$ at an elevation range of 1,280-1,700 $\mathrm{m}$ on north- and northwest-facing slopes. Much of the 2,000-3,000 mm of annual precipitation occurs as winter snow, and we estimate the mean temperature to be $4-6{ }^{\circ} \mathrm{C}$ (Decker 2001). Our study sites are located in the phytogeographic transition zone between semi-arid, Mediterranean-type climate to the north and cool temperate rain forest climate to the south. Thus, our study sites exist in a tension zone between warm and cool temperate Nothofagus forests. Understory plant diversity and biomass are generally low; the scattered shrub layer consists mainly of dense patches of Chusquea spp. (a native bamboo). The parent materials in which the soils of these sites were formed are all recent volcanic deposits dominated by fine pumice fragments. The 
texture of the soil at each of the study sites was predominantly silt loam. More details of the study area are given by Decker (2001).

We chose a total of five single species and mixed species stands within this study area to test our hypotheses during the 1995 and 1996 austral growing seasons (Table 1). We chose one stand dominated by each of the three Nothofagus species as our single species stands. Whereas both deciduous species stands were $100 \%$ pure, the stand dominated by $N$. dombeyi did have a few patches of $N$. obliqua seedlings and saplings in it. In both 1995 and 1996 we also sampled a three species stand in which $N$. dombeyi, N. obliqua, and N. pumilio canopy trees were present in a ratio of $2: 1: 1$ (Table 1). In 1996 we added a two species stand that was approximately $22 \% N$. dombeyi and $78 \% N$. obliqua. The structure and age distributions of these stands are described in more detail by Decker (2001).

Nothofagus obliqua (Mirb.), common name: roble, is a drought-tolerant, deciduous tree species whose leaves remain on the tree for a full 6-7 month growing season. It occurs at mid- to low-elevations throughout central Chile from $33^{\circ}$ to $41^{\circ} 30^{\prime} \mathrm{S}$ latitude mountain ranges, foothills, and the Central Depression (Donoso
1974). Nothofagus dombeyi (Mirb.), common name: coigue, is the northernmost in distribution of the three evergreen species of Nothofagus occurring in Chile It occurs from $34^{\circ} 40^{\prime}$ to $48^{\circ} \mathrm{S}$ latitude at elevations ranging from near sea level to approximately $2,500 \mathrm{~m}$ in the Andes and Coastal Cordillera (Donoso 1974). In our study area, $N$. dombeyi leaves live up to four years (Hevia et al. 1999).

Nothofagus pumilio (Poepp. et Endl.), common name: lenga, is a deciduous species with a leaf lifespan of one growing season. Nothofagus pumilio is a cold-tolerant species that occurs at higher elevations, following the Andean tree line from latitude $35^{\circ} 40^{\prime}$ (just north of our study area) to $55^{\circ} \mathrm{S}$ latitude in Tierra del Fuego (Tortorelli 1956, Donoso 1974).

\section{Field methods}

In October 1995 we collected samples from the top $15 \mathrm{~cm}$ of mineral soil in the three single species stands and the three species stand. Three undamaged canopy trees were chosen within an area of 1.5-3.0 ha for each species in each forest stand. We collected soil upslope, down slope, and along the slope

TABLE 1

Characteristics of five forest stands within a mixed Nothofagus forest located between Las Termas de Chillan and Las Trancas in the Chilean Andes. The mean age is given for the single species and two species stands, and the age of the oldest tree in single species stands is given in parentheses

Características de cinco rodales forestales de Nothofagus entre las localidades de Termas de Chillán y Las Trancas en los Andes chilenos. Entre paréntesis se incluye la edad promedio para los rodales mono y bi-específicos, así como la mayor edad registrada en rodales monoespecíficos

\begin{tabular}{|c|c|c|c|c|}
\hline Stand & $\begin{array}{l}\text { Elevation } \\
\quad(\mathrm{m})\end{array}$ & $\begin{array}{c}\text { Species } \\
\text { present } \\
\text { in canopy }\end{array}$ & $\begin{array}{c}\text { Basal } \\
\text { area } \\
(\%)\end{array}$ & $\begin{array}{l}\text { Stand } \\
\text { age } \\
(\mathrm{yr})\end{array}$ \\
\hline N. obliqua & $1,280-1,400$ & N. obliqua & 100 & $\begin{array}{r}38 \\
(175)\end{array}$ \\
\hline N. dombeyi & $1,290-1,345$ & $\begin{array}{r}\text { N. dombeyi } \\
\text { N. obliqua }\end{array}$ & $\begin{array}{r}99.3 \\
0.7\end{array}$ & $\begin{array}{r}85 \\
(270)\end{array}$ \\
\hline Two species & $1,365-1,400$ & $\begin{array}{c}\text { N. obliqua } \\
\text { N. dombeyi }\end{array}$ & $\begin{array}{l}43.8 \\
56.2\end{array}$ & $\begin{array}{l}42 \\
36\end{array}$ \\
\hline Three species & $1,420-1,470$ & $\begin{array}{l}\text { N. obliqua } \\
\text { N. dombeyi } \\
\text { N. pumilio }\end{array}$ & $\begin{array}{r}8.5 \\
80.3 \\
11.1\end{array}$ & $\begin{array}{l}\text { No data } \\
\text { No data } \\
\text { No data }\end{array}$ \\
\hline N. pumilio & $1,600-1,630$ & N. pumilio & 100 & $\begin{array}{r}68 \\
(300)\end{array}$ \\
\hline
\end{tabular}


contour parallel to each tree at three distances: adjacent to the tree base: approximately $1 \mathrm{~m}$ from the tree base, and from under the edge of the canopy (i.e., at the drip line) of each tree. This yielded a total of $n=27$ per stand for the single species stand $n=71$ for the three species mixed stand.

In November-December 1996 we again sampled the three single species stands and the three species mixed stand, and also sampled a two species ( $N$. dombeyi-N. obliqua) stand. In 1996 we increased the number of trees per species per stand from three to six, and reduced the number of soil samples per tree from nine to four. For each tree, two samples were collected at approximately $1 \mathrm{~m}$ from the tree base and two under the canopy. This yielded a total of $n=24$ for the single species stands, $\mathrm{n}=72$ for the three species stand and $n=48$ for the two species stand. New canopy trees were randomly chosen in 1996 so no individuals were represented in both the 1995 and 1996 results. All samples were air-dried to constant mass then shipped to Ohio State University for analysis.

\section{Laboratory methods}

Soil samples were passed through a $6 \mathrm{~mm}$ sieve to remove rocks, roots, and buried leaves. Inorganic $\mathrm{N}$ and $\mathrm{P}$ were extracted from $20 \mathrm{~g}$ subsamples with $40 \mathrm{~mL}$ of $2 \mathrm{M} \mathrm{KCl}$ and the extracts frozen pending analysis. $\mathrm{NO}_{3}{ }^{-}$and $\mathrm{NH}_{4}{ }^{+}$ concentrations in extracts were determined using a Lachat Quikchem Autoanalyzer. Soil pH was determined in 1:3 w:v slurries using $0.01 \mathrm{M}$ $\mathrm{CaCl}_{2}$ (Hendershot et al. 1993). Plant available $\mathrm{P}$ (as $\mathrm{PO}_{4}{ }^{3-}$ ) was determined using the ammonium molybdate/stannous chloride method (APHA 1976). Soil organic C was quantified using the Walkley-Black method (Allison 1965).

Subsamples of approximately $70 \mathrm{~g}$ were placed into styrofoam cups for aerobic laboratory incubations using methods described by Morris and Boerner (1998). Each incubating subsample was weighed every 2-3 days, and the soil moisture brought back to a randomly chosen level between 50 and $70 \%$ of field capacity with Hubbard Brook recipe artificial rainwater (Lee \& Weber 1979). These moisture fluctuations were designed to mimic those typical of humid, temperate forests (Morris \& Boerner 1998, Boerner et al. 2000). At the end of the 24-29 day incubation period, $\mathrm{NO}_{3}{ }^{-}$and $\mathrm{NH}_{4}{ }^{+}$were extracted from of incubated soil and $\mathrm{NO}_{3}{ }^{-}$and $\mathrm{NH}_{4}{ }^{+}$concentrations in soil extracts determined as above.

Net $\mathrm{N}$ mineralization potential was calculated as the difference between $\mathrm{NO}_{3}{ }^{-}+$
$\mathrm{NH}_{4}{ }^{+}$in pre-incubation and post-incubation soils. Net nitrification was calculated as the difference in $\mathrm{NO}_{3}{ }^{-} \mathrm{N}$ concentration in preincubation and post-incubation soils. Proportional nitrification was calculated as the amount of $\mathrm{NO}_{3}{ }^{-}-\mathrm{N}$ evolved during the incubation period as a percentage of the $\mathrm{NH}_{4}{ }^{+}$ $\mathrm{N}$ available for nitrification (i.e., net $\mathrm{N}$ mineralized $+\mathrm{NH}_{4}{ }^{+}-\mathrm{N}$ present at the beginning of the incubation period).

Laboratory incubations were chosen for this study because the distance and expense of travelling to the field sites precluded the multiple visits required to complete in situ incubations. In addition, the use of aerobic incubations with fluctuating moisture levels has been demonstrated in the past to be a reliable method for assessing variations in net $\mathrm{N}$ mineralization and nitrification at the landscape scale (Boerner \& LeBlanc 1995, Morris \& Boerner 1998, Boerner et al. 2000).

\section{Statistical analysis}

All response variables were normally distributed (PROC UNIVARIATE/NORMAL, SAS Institute 1995). The relationship between response variables and elevation was tested by linear regression using only those samples for which the precise elevation of the sample tree was known. In 1995, we had difficulties with the measurement of the elevation of individual trees so only the 1996 data were analyzed in this manner (PROC GLM, SAS Institute 1995).

We used Analysis of Variance to analyze differences in soil collected under trees among stands. Each year was analyzed separately. In cases where main effects were significant, the Ryan-Einot-Gabriel-Welsch modified Q test (PROC GLM/REGWQ, SAS Institute 1995) was used to separate means. This post-test was chosen because it minimizes type I errors (SAS Institute 1995).

\section{RESULTS}

\section{Influence of elevation}

Linear regression revealed no significant change in net $\mathrm{N}$ mineralization rates over the $350 \mathrm{~m}$ elevational range we sampled, either for all tree species taken together or for each species individually (Fig. 1). There was a statistically significant decrease in proportional nitrification with elevation $\left(\mathrm{P}<0.014, \mathrm{r}^{2}=0.03\right)$ (Fig. 1); however, elevation accounted for little of the variance in nitrification. In contrast, there were 
no significant relationships between elevation and nitrification for any of the three tree species taken individually (Fig. 1).

Soil $\mathrm{pH}$ did not vary significantly with elevation overall or for soils taken from under $N$. dombeyi or $N$. obliqua (Fig. 2). Soil pH did decrease significantly, though weakly, with elevation in soils taken under $N$. pumilio trees $\left(\mathrm{P}<0.020, \mathrm{r}^{2}=0.13\right)$ (Fig. 2). Available $\mathrm{P}$ in the soil did not vary significantly with elevation for all three species taken together, for soils from under $N$. dombeyi, or for soils from under $N$. pumilio (Fig. 2). In contrast, available $\mathrm{P}$ did decrease significantly with elevation in soils from under $N$. obliqua trees $\left(\mathrm{P}<0.001, \mathrm{r}^{2}=0.25\right)$ (Fig. 2). Soil organic $\mathrm{C}$ decreased significantly with elevation for soils taken from under all tree species together $(\mathrm{P}<$ $\left.0.001, \mathrm{r}^{2}=0.019\right), N$. obliqua alone $(\mathrm{P}<0.001$, $\left.\mathrm{r}^{2}=0.33\right)$, and N. pumilio alone $\left(\mathrm{P}<0.022, \mathrm{r}^{2}=\right.$ 0.013 ), but not for $N$. dombeyi alone (Fig. 3).

Overall, $\mathrm{N}$ dynamics and soil $\mathrm{pH}$ varied little with elevation while soil organic C decreased significantly with elevation. Available $\mathrm{P}$ decreased significantly with elevation in soils dominated by $N$. obliqua, but not otherwise.

\section{Influence of vegetation types}

In $1995 \mathrm{~N}$ mineralization rates in the soils of the $N$. obliqua and $N$. dombeyi stands did not differ significantly, whereas in 1996 soils from the $N$. obliqua stands mineralized $\mathrm{N}$ at a significantly greater rate than did those from the $N$. dombeyi stand (Fig. 4). Nitrogen mineralization rates in soils from the $N$. pumilio stand were similar to those observed in the $N$. dombeyi stand in both years. Soils from the mixed species stands had among the lowest $\mathrm{N}$ mineralization rates we observed.

Nitrification was greatest in soils collected under trees in the $N$. obliqua stand in both 1995 and 1996 (Fig. 4). In both years, nitrification was almost non-existent in soils from the $N$. pumilio and $N$. dombeyi stands. Nitrification in
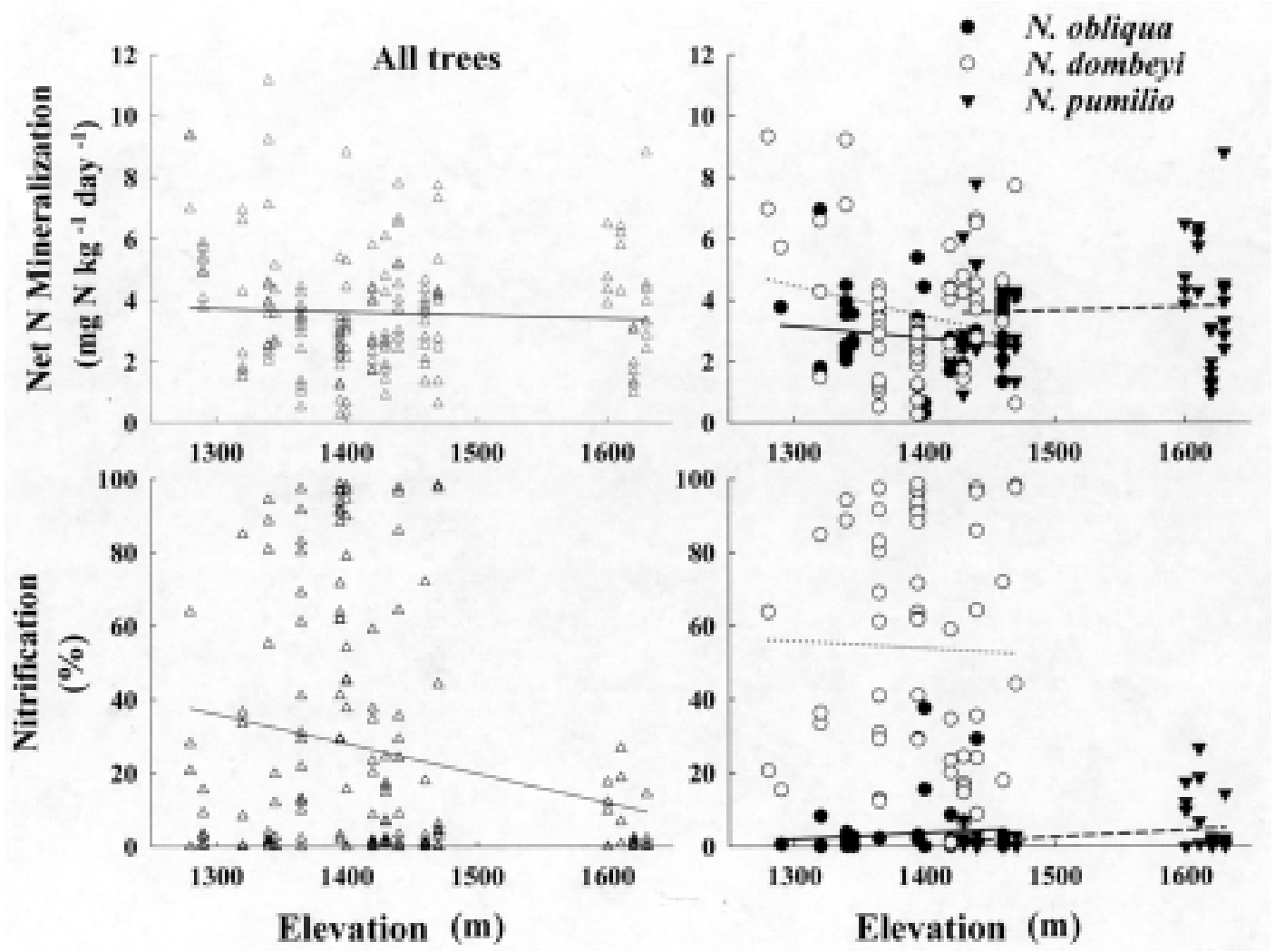

Fig. 1: Linear regression of soil $\mathrm{N}$ dynamics on elevation for 1996 samples. Regression lines for individual species are indicated as N. obliqua (dotted line), N. dombeyi (solid line), and N. pumilio (dashed line).

Relación entre la elevación y la dinámica de nitrógeno en el suelo, para las muestras de 1996. Se muestran las regresiones lineales para las especies en forma separada: N. obliqua (línea punteada), N. dombeyi (línea continua), y N. pumilio (línea discontinua). 

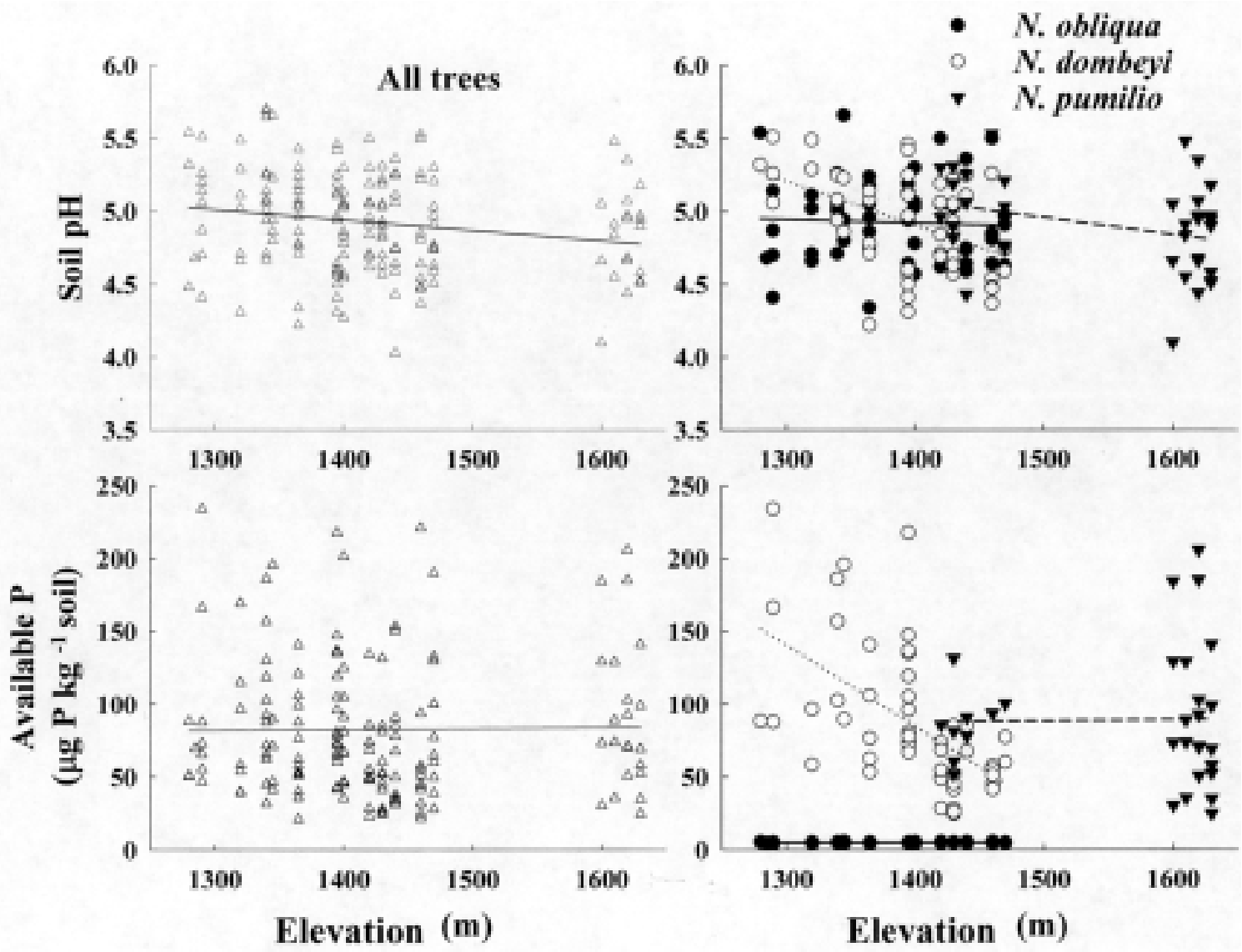

Fig. 2: Linear regression of soil $\mathrm{pH}$ and $\mathrm{P}$ content on elevation for 1996 samples. Regression lines for individual species are indicated as $N$. obliqua (dotted line), N. dombeyi (solid line), and $N$. pumilio (dashed line).

Relación entre la elevación y el pH y el contenido de P del suelo, para las muestras de 1996. Se muestran las regresiones lineales para las especies en forma separada: $N$. obliqua (línea punteada), $N$. dombeyi (línea continua), y $N$. pumilio (línea discontinua).

the mixed species stands was intermediate between those of the pure stands (Fig. 4).

In both 1995 and 1996 soils from the evergreen $N$. dombeyi stands had significantly lower soil $\mathrm{pH}$ than those from the deciduous $N$. obliqua stand (Fig. 5). Soil $\mathrm{pH}$ in the $N$. pumilio stand was intermediate between the other two pure stands in 1995 and similar to that in the N. dombeyi stand in 1996 (Fig. 5). Once again, in both years the soil $\mathrm{pH}$ in the mixed species stands was intermediate.

Just as was the case for $\mathrm{N}$ mineralization, plant available $\mathrm{P}$ did not differ significantly between $N$. obliqua and $N$. dombeyi stands in 1995 but in $1996 \mathrm{P}$ was more available in the soils of the $N$. obliqua stand than in the $N$. dombeyi stand (Fig. 5). Soils in the N. pumilio stand had among the highest available P levels we observed. Phosphorus levels in mixed species stands were most similar to those from the pure $N$. dombeyi stand (Fig. 5).

In 1995 soil organic $\mathrm{C}$ content did not differ significantly between the pure $N$. dombeyi stand and the pure $N$. obliqua stand, whereas in 1996 organic C content in N. obliqua stands was approximately $45 \%$ greater than that in $N$. dombeyi soils (Fig. 5). Organic C content of soils in the high elevation $N$. pumilio soils was significantly lower than those of the other single species stands in 1996, but not in 1995 (Fig. 5). Organic $\mathrm{C}$ content in soils of mixed species stands was intermediate between those of the pure stands in 1996 and similar to that of the N. obliqua stand in 1995 (Fig. 5).

Although the landscape patterns in soil chemistry varied somewhat between the two 

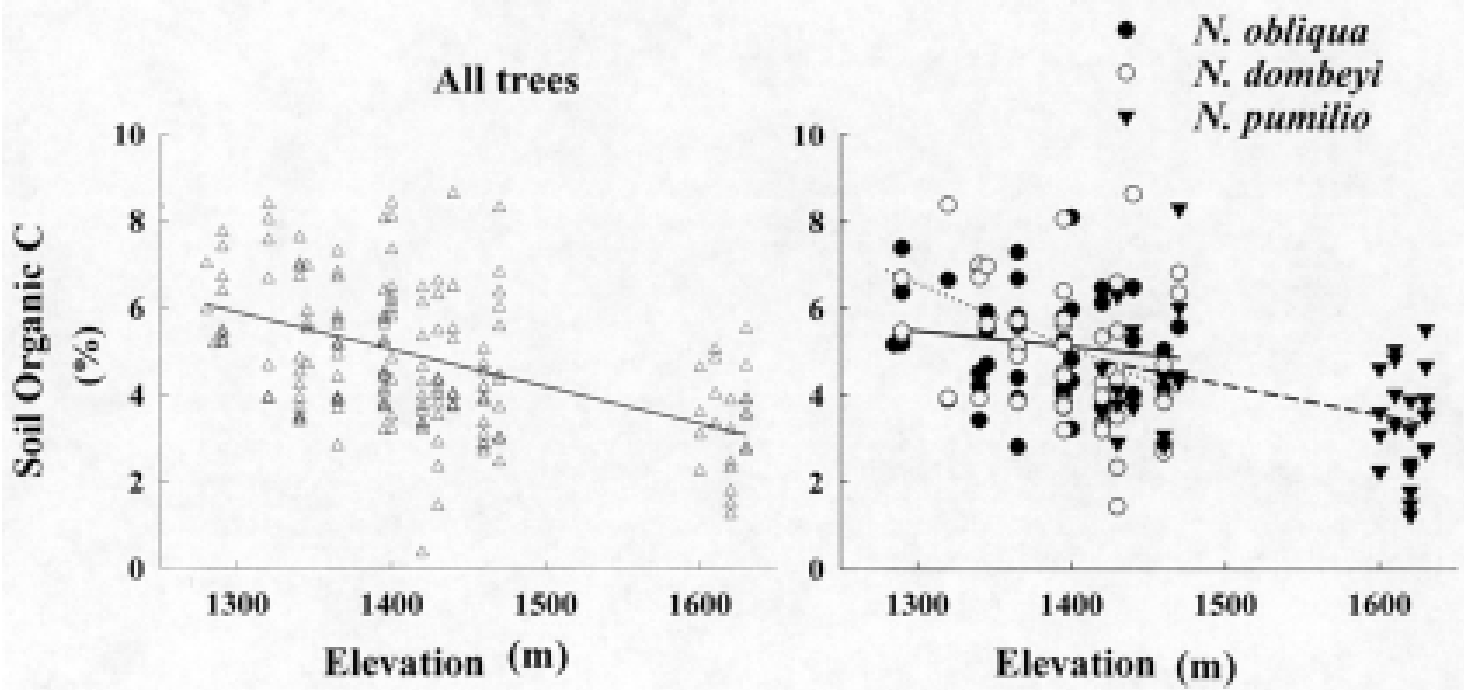

Fig. 3: Linear regression of soil organic C content on elevation for 1996 samples. Regression lines for individual species are indicated as $N$. obliqua (dotted line), $N$. dombeyi (solid line), and $N$. pumilio (dashed line).

Relación entre la elevación y el C orgánico del suelo, para las muestras de 1996. Se muestran las regresiones lineales para las especies en forma separada: N. obliqua (línea punteada), N. dombeyi (línea continua), y N. pumilio (línea discontinua).

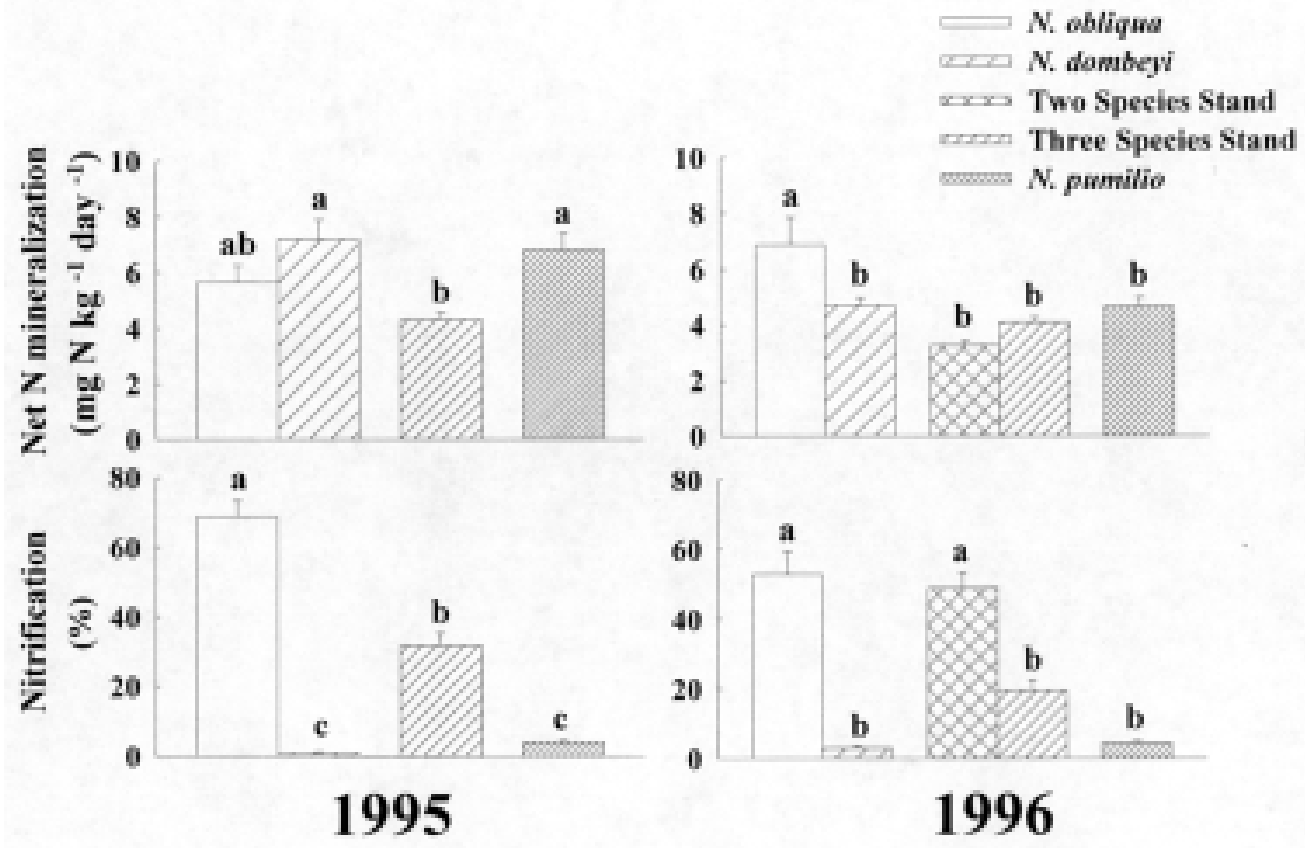

Fig. 4: Comparison of soil $\mathrm{N}$ dynamics in soils collected in five forest stands near Las Trancas, Chile. Histogram bars represent means with standard errors of the means indicated. Histograms on the left represent 1995 samples and those on the right 1996 samples. Mean stand elevation increases to the right. Means that were not significantly different at $\mathrm{P} \leq 0.05$ are indicated by the same lower case letter.

Dinámica de $\mathrm{N}$ del suelo recolectado en cinco rodales forestales cerca de Las Trancas, Chile. Las barras de los histogramas representan promedios, con error estándar. Los histogramas a la izquierda representan las muestras de 1995 y los de la derecha las muestras de 1996. La elevación aumenta hacia la derecha. Los promedios que no difieren significativamente (P $\leq 0,05)$ comparten la misma letra en minúscula. 


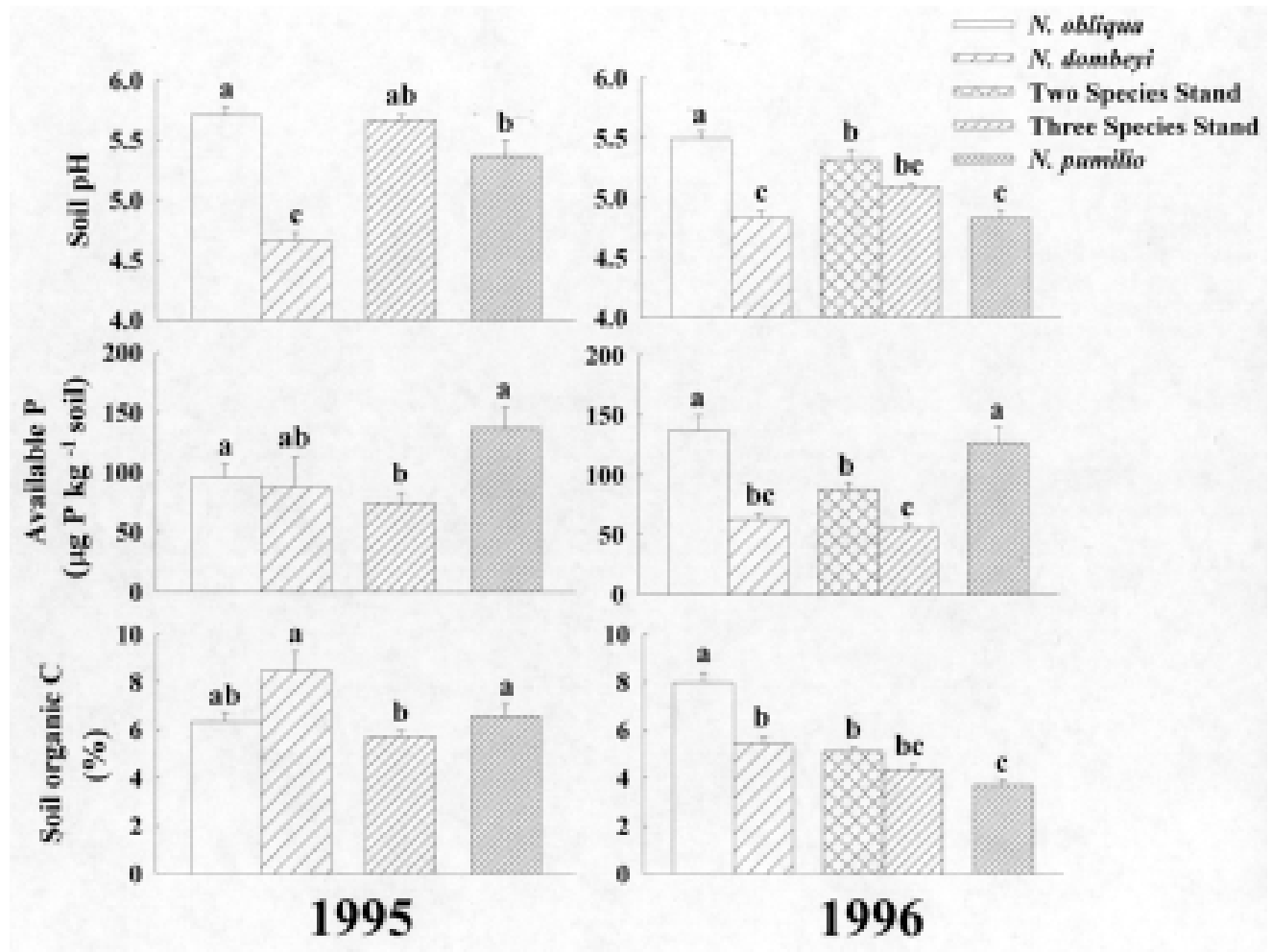

Fig. 5: Comparison of soil $\mathrm{pH}$, plant available $\mathrm{P}$, and soil organic $\mathrm{C}$ in soils collected in five forest stands near Las Trancas, Chile. Histogram bars represent means with standard errors of the means indicated. Histograms on the left represent 1995 samples and those on the right 1996 samples. Mean stand elevation increases to the right. Means that were not significantly different at $\mathrm{P} \leq 0.05$ are indicated by the same lower case letter.

Datos de pH, P disponible, y C orgánico del suelo recolectados en cinco rodales forestales cerca de Las Trancas, Chile. Las barras de los histogramas representan promedios, con error estándar. Los histogramas a la izquierda representan las muestras de 1995 y los de la derecha las muestras de 1996. La elevación aumenta hacia la derecha. Los promedios que no difieren significativamente $(\mathrm{P} \leq 0,05)$ comparten la misma letra en minúscula.

sample years, in general soils from the $N$. obliqua stand had high rates of nitrification, the highest $\mathrm{pH}$, and the greatest content of organic $\mathrm{C}$ and plant available $\mathrm{P}$. In contrast, soils from the $N$. dombeyi and $N$. pumilio stands had lower soil $\mathrm{pH}$ and almost no detectable nitrification. The two multi-species stands tended to be intermediate in soil properties between maximums found in the single species stands.

\section{DISCUSSION}

Our hypothesis was that rates of $\mathrm{N}$ mineralization and nitrification would decrease with increasing elevation as a result of changes in microclimate and, possibly, changes in vegetation-soil interactions. Our data do not support this hypothesis to any appreciable degree. Although there was a statistically significant decrease in nitrification with increasing elevation when all species were taken together, the proportion of the variance in nitrification rates explained by elevation over our $350 \mathrm{~m}$ gradient was small, and we observed no statistically significant effect of elevation on nitrification for soils taken under any of the three species individually. In addition, we observed no significant relationship between elevation and net $\mathrm{N}$ mineralization rate for any of the three species or for the entire pooled data set.

We also hypothesized that soil $\mathrm{pH}$ and available $\mathrm{P}$ would decrease with elevation while organic $\mathrm{C}$ content would increase with elevation. Once again, we find little in our data to support this hypothesis. Soil pH did not vary in any ecologically significant manner with elevation, and significant changes in available $\mathrm{P}$ with elevation were limited to a decrease observed in $\mathrm{P}$ in soils taken under $N$. obliqua that accounted for only $25 \%$ of the variance in $\mathrm{P}$ among those samples. Organic C content decreased with elevation overall and in soils from both of the 
deciduous species, though elevation explained only a small proportion of the variance in organic $\mathrm{C}$ content among the soils we analyzed. Overall, we found little indication that elevation alone or an interaction between elevation and leaf lifespan significantly affects soil properties linked to plant growth and vigor along this elevation gradient.

The lack of a strong elevation effect in organic matter and $\mathrm{N}$ turnover in our Chilean study sites is consistent that reported by Knoepp \& Swank (1998) in their study in the southern Appalachian Mountains of eastern North America. Knoepp \& Swank (1998) reported that elevation was less of a factor than vegetation type in controlling $\mathrm{N}$ mineralization over a $565 \mathrm{~m}$ elevation range. Given the relatively young soils of our study sites, we would have anticipated that they would be relatively P-rich and N-poor (Walker \& Syers 1976), and therefore N limited. However, our data force us to conclude that elevation-driven changes in $\mathrm{N}$ mineralization and nitrification (and thereby $\mathrm{N}$ supply to trees) are insufficient, in and of themselves, to explain the variations in Nothofagus species' distributions along this elevation gradient.

The corollary to our first hypothesis was that $\mathrm{N}$ availability would be lower under the canopy of the evergreen species than under the canopies of the two deciduous species. In 1996, when we sampled during the part of the growing season in which microbial activity might be expected to be greatest (Plymale et al. 1987), we found soils under the deciduous $N$. obliqua to support significantly greater $\mathrm{N}$ mineralization and nitrification than did soils under the other two species. Thus, this corollary hypothesis is supported by our data with respect to $N$. obliqua: $N$. obliqua is most abundant on soils with greater $\mathrm{N}$ turnover and potential availability, at least as compared to the evergreen $N$ dombeyi. However, once again we observe little difference in the soil $\mathrm{N}$ dynamics in soils supporting the evergreen $N$. dombeyi and the upper-elevation, deciduous $N$. pumilio, so the relationship between leaf lifespan and soil $\mathrm{N}$ turnover/availability may hold only under relatively mesic conditions, and succumb to the overriding effects of climate under marginal conditions such as those near tree line.

Goldberg (1982) suggested that the distribution of evergreen species in low nutrient soils is a result of competitive exclusion by faster growing deciduous species; yet Knops \& Koenig (1997) found no differences in total N in soil under evergreen and deciduous species of Quercus in a California oak savanna. Knops \& Koenig (1997) suggest that the competition for $\mathrm{N}$ rich sites between evergreen and deciduous trees in an open grassy savanna may not be the controlling factor in the relative distribution of these species. Our Nothofagus stands are comparatively dense, high biomass forests where belowground competition for nutrients is more likely to be occurring among trees than in the open, less-dense California savanna, and we found $N$. dombeyi growing in soils that were $\mathrm{N}$ poor relative to those of the $N$. obliqua stand.

Other more mechanistic studies have also shown differential effects of evergreen and deciduous trees on soil $\mathrm{N}$ cycling. For example, Ferrari (1999) quantified litter lignin:N ratios and their effects on soil $\mathrm{N}$ cycling of several evergreen and deciduous species in a Michigan (USA) forest. He found that evergreen conifer litter had higher lignin:N, and that high lignin:N in litter was negatively correlated with $\mathrm{N}$ mineralization and nitrification rates (Ferrari 1999). Decker (2001) found that mean lignin: $N$ in litter of $N$. obliqua, $N$. dombeyi and $N$. pumilio (collected in the three species stand) was $21.7(\mathrm{SE}=3.6), 27.5(\mathrm{SE}=3.6)$, and 41.7 $(\mathrm{SE}=13.1)$, respectively. Although these litter lignin: $\mathrm{N}$ ratios do not significantly differ, they do illustrate a similar pattern to the nitrification rates reported here. In our study area, Hevia et al. (1999) found foliar $\mathrm{N}$ to be lowest in $N$. dombeyi leaves, intermediate in $N$. pumilio leaves, and highest in N. obliqua leaves. As leaf $\mathrm{N}$ resorption did not differ among these species, these differences in $\mathrm{N}$ concentrations carried over to the leaf litter, and thus to soil $\mathrm{N}$. However, one must be cautious in making the extension from enhanced leaf litter $\mathrm{N}$ concentrations to increased $\mathrm{N}$ mineralization solely on the basis of correlation, as Knops \& Koenig (1997) found that summer leaf $\mathrm{N}$ in evergreen and deciduous Quercus spp. correlated with soil available $\mathrm{N}$ but not with litter $\mathrm{N}$ concentration.

The organic $\mathrm{C}$ content of the soils under these five forests varied relatively little, and in no consistent fashion with leaf life span. In 1995, we observed the greatest soil organic C content in the soils from the $N$. dombeyi stand whereas in 1996 the greatest soil organic C was found in the $N$. obliqua stand. Combining this observation with the strong patterns of $\mathrm{N}$ mineralization and nitrification described above leads us to the conclusion that organic matter quality (i.e., $\mathrm{C}: \mathrm{N}$ ratio) varies among these five forest stands much more than does organic matter quantity (i.e., total $\mathrm{C}$ content). 
Soil $\mathrm{pH}$ was consistently higher in the soils of the N. obliqua stand than in those of the $N$. dombeyi stand, suggesting a strong link between leaf lifespan and soil $\mathrm{pH}$. However, soil $\mathrm{pH}$ in the upper-elevation, deciduous $N$. pumilio stand was not significantly different from that of the lower-elevation $N$. obliqua stand in 1995 and 1996, and not significantly different from that in the evergreen $N$. dombeyi stand in 1996. This pattern more clearly suggested a significant interaction between elevation and leaf lifespan than did that of any other parameter we measured.

Plant available $\mathrm{P}$ was consistently greatest in the upper elevation $N$. pumilio stand. We attribute this to a combination of relatively low uptake demand in this open, less dense and lower biomass stand and greater rates of physiochemical weathering of the young, volcanically-derived parent material at the higher elevation (Walker \& Syers 1976).

What have these observations taught us about the factors controlling the distribution of these three species in this region, and to what new research directions do our results point? In the absence of higher $\mathrm{N}$ mineralization rates, the high nitrification in soils under $N$. obliqua in the mixed stands and in the pure $N$. obliqua stand can be attributed to a supply of inorganic $\mathrm{N}$ that exceeds plant and heterotrophic soil microbe needs, as nitrifiers are relatively poor competitors for $\mathrm{NH}_{4}^{+}$(Aber et al. 1989). It is energetically inefficient for plants to utilize $\mathrm{NO}_{3}{ }^{-}$, as $\mathrm{NO}_{3}{ }^{-}$must to be reduced to $\mathrm{NH}_{2}{ }^{-}$before it can be incorporated into amino acids. This can be accomplished via the nitrate reductase pathway by the plant itself or by the fungal partner in an ectomycorrhizal association (France \& Reid 1983). It would be interesting to determine if the relative success $N$. obliqua exhibits on high $\mathrm{NO}_{3}{ }^{-}$soils is related to differences in ectomycorrhizal symbionts among Nothofagus species.

We observed clear differences in soil $\mathrm{N}$ dynamics in $N$. obliqua versus $N$. dombeyi stands that could not be explained by differences in elevation alone. Under $N$. dombeyi trees, nitrification was consistently low, even when $\mathrm{N}$ mineralization rates were as high as those supporting considerable nitrification under $N$. obliqua. This suggests higher $\mathrm{NH}_{4}{ }^{+}$demand by plants and heterotrophic microbes under $N$. dombeyi than $N$. obliqua, a low abundance of nitrifying bacteria under $N$. dombeyi, or the presence of other factors that limit the activity of nitrifiers more under $N$. dombeyi than under $N$. obliqua. Hart et al. (1994) found a low rate of nitrate release in coniferous forest soil incubated in the lab, until after 140 days, when they observed a large increase in soil $\mathrm{NO}_{3}{ }^{-}$that correlated with a reduction in microbial biomass. They postulated that the low net nitrification rates were due to high $\mathrm{NO}_{3}$ immobilization by heterotrophic microbes (i.e., high gross nitrification but low net nitrification). We did not measure gross nitrification in our $N$. dombeyi stands, but the lack of nitrification under these trees and in $N$. dombeyi single species stands may also indicate a greater ability to retain $\mathrm{N}$ in the system than in corresponding $N$. obliqua soils. Decker (2001) found the litter quality differed between species $(N$. obliqua $\mathrm{C}: \mathrm{N}$ ratio of 40.7 and $N$. dombeyi 59.8) and also determined in a common plot experiment that net $\mathrm{N}$ release from decomposing $N$. dombeyi litter was much slower than that from $N$. obliqua litter. Analysis of microbial biomass, activity, and organic matter turnover rate in soils and litter from under $N$. obliqua and $N$. dombeyi may shed further light on this.

Contrary to what we hypothesized, soils under the deciduous $N$. pumilio were similar to those under the evergreen $N$. dombeyi. Nothofagus pumilio has a high elevation or high latitudinal distribution, similar to many northern hemisphere conifers. Thus the adaptations necessary for the survival of $N$. pumilio in these mountainous, cold, and windy areas may include the ability to persist under strong $\mathrm{N}$ limitation. Instead of retaining scarce $\mathrm{N}$ for long periods of time in evergreen leaves with relatively low photosynthetic capacity, as conifers do, $N$. pumilio may be have adopted the strategy of building high $\mathrm{N}$, low $\mathrm{C}$ leaves adapted for high photosynthetic rates (at least in relation to temperature) for a short leaf lifespan.

In this study we have demonstrated that soil $\mathrm{N}$ transformation rates, $\mathrm{pH}$, and plant available $\mathrm{P}$ supplies do differ among stands occupied by different Nothofagus species, and have shown that the distribution of the deciduous $N$. obliqua correlates closely with soils that support high net nitrification rates. We have also shown that organic matter quality varies more among these forest stands than does organic matter quality. However, our study has yielded little insight into the controls over the relative distributions of the evergreen $N$. dombeyi and the deciduous $N$. pumilio at upper elevations. It is hoped that on-going studies of relative growth rates and foliar $\mathrm{C}$ dynamics in these two species will clarify what this study of soil $\mathrm{N}$ dynamics has not. 


\section{ACKNOWLEDGMENTS}

This research was supported by Grants-In-Aid of Research from Sigma Xi, the Janice Carson Beatley Herbarium Awards for Field Research, the Latin American Studies/Tinker Grants Program of Ohio State University, and The National Science Foundation. We thank Jennifer Brinkman and Melissa Knorr for laboratory assistance, Loretto Minoletti and Erik Harvey for field assistance, Nidia Arguedas, Chris Lusk, and Richard Kolyer for translation assistance, Felicitas Hevia and the Universidad de Concepción, Chillán for sponsorship and laboratory space, and Rachel Thiet and two anonymous reviewers for comments on an earlier draft of this manuscript.

\section{LITERATURE CITED}

ABER JD, KJ NADELHOFFER, P STEUDLER\& JM MELILLO (1989) Nitrogen saturation in northern forest ecosystems. BioScience 39: 378-386.

ALLISON LE (1965) Organic carbon. In: Black CA, DD Evans, JL White, LE Ensminger \& FE Clark (eds) Methods of soil analysis, Part 2: chemical and microbiological properties: 1367-1378. American Society of Agronomy, Madison, Wisconsin, USA.

ALWAY FJ, J KITTREDGE \& WJ METHLEY (1933) Composition of the forest floor layers under different forest types on the same soil type. Soil Science 35: 387-398.

AMERICAN PUBLIC HEALTH ASSOCIATION (1976) Standard methods for the examination of water and wastewater. Fourteenth edition. American Public Health Association, Washington, District of Columbia, USA. 1,193 pp.

BOERNER REJ, SJ MORRIS, EK SUTHERLAND \& TF HUTCHINSON (2000) Spatial variability in soil nitrogen dynamics after prescribed burning in Ohio mixed-oak forests. Landscape Ecology 15: 425-439.

BOETTCHER SE \& PJ KALISZ (1990) Single tree influence on soil properties in the mountains of eastern Kentucky. Ecology 71: 1365-1372.

CHABOT BF \& DJ HICKS (1982) The ecology of leaf life spans. Annual Review of Ecology and Systematics 13: $229-259$

DECKER KLM (2001) Ecophysiological and edaphic studies of Chilean Nothofagus forests. Ph.D. Dissertation, Department of Evolution, Ecology, and Organismal Biology, Ohio State University, Columbus, Ohio, USA. 165 pp.

DONOSO C (1974) Dendrología: árboles y arbustos chilenos. Universidad de Chile, Faculdad de Ciencias Forestales, Manual No. 2., Santiago, Chile. 143 pp.

HART SC, GE NASON, DD MYROLD \& DA PERRY (1994) Dynamics of gross nitrogen transformations in an old-growth forest: the carbon connection. Ecology 75: 880-891.

HEVIA F, ML MINOLETTI, KLM DECKER \& REJ BOERNER (1999) Foliar nitrogen and phosphorus dynamics of three Chilean Nothofagus (Fagaceae) species in relation to leaf lifespan. American Journal of Botany 86: 447-455.

FERRARI JB (1999) Fine scale patterns of leaf litterfall and nitrogen cycling in an old growth forest. Canadian Journal of Forest Research 29: 291-302.

FRANCE RC \& CPP REID (1983) Interactions of nitrogen and carbon in the physiology of ectomycorrhizae. Canadian Journal of Botany 61: 964-984.

GOLDBERG DE (1982) The distribution of evergreen and deciduous trees relative to soil type: an example from the Sierra Madre, Mexico, and a general model. Ecology 63: 942-951.

KNOEPP JD \& WT SWANK (1998) Rates of nitrogen mineralization across an elevation and vegetation gradient in the southern Appalachians. Plant and Soil 204: 235-241.

KNOPS JMH \& WD KOENIG (1997) Site fertility and leaf nutrients of sympatric evergreen and deciduous species in central coastal California. Plant Ecology 130: 121-131.

LEE JJ \& DE WEBER (1979) The effect of simulated acid rain on seedling emergence and growth of eleven woody species. Forest Science 23: 393-398.

MEENTEMEYER V (1978) Microclimate and litter control over litter decomposition rates. Ecology 59: 486-472.

MORRIS SJ \& REJ BOERNER (1998) Landscape patterns of nitrogen mineralization and nitrification in southern Ohio hardwood forests. Landscape Ecology 13: 215-224

PLYMALE AE, REJ BOERNER \& TJ LOGAN (1987) Relative nitrogen mineralization and nitrification in soils of two contrasting hardwood forests: effects of site microclimate and initial soil chemistry. Forest Ecology and Management 21: 21-36.

SAS INSTITUTE (1995) Statistical analysis system user's guide: statistics (on line documentation) SAS Institute, Cary, North Carolina, USA. 864pp.

SHANKS RE \& JS OLSEN (1961) First-year breakdown of leaf litter in southern Appalachian forests. Science 134: 194-195.

TORTORELLI LA (1956) Maderas y bosques argentinos. Editorial ACME, Buenos Aires, Argentina. 910 pp.

WALKER TW \& JK SYERS (1976) The fate of phosphorous during pedogenesis. Geoderma 15: 1-19. 